\title{
The Role Of Business Education At The K-12 Level: Faculty Perceptions On Establishing A Business Education Department In The College Of Basic Education At The Public Authority For Applied Education And Training
}

Abdullah AlSagheer, Colorado State University USA

Areej Al-Sagheer, Kuwait Petroleum International, Kuwait

\begin{abstract}
In recent years, business education has grown rapidly at the university level, though there have been some critics who believe that this approach does not instill the outcomes that business schools claim. One possible approach suggested is the expansion of business education to general education at the K-12 level in order to better instill business skills among the general student population. The validity of this theory and the proposal to add a business education component to the College of Basic Education at The Public Authority for Applied Education and Training in The State of Kuwait was tested using the perspectives gathered through interviews of six faculty members from the College of Basic Education and the College of Business Studies. The interviews revealed varying opinions between the two faculties on the usefulness of business education generally, the applicability of business skills, and the importance of teaching business ethics. Though the hypothesis is ultimately not fully supported, the perspectives given provide a good start for considering expanding business education to the K-12 level.
\end{abstract}

Keywords: business education, business ethics, teaching business, faculty perspective, PAAET

\section{INTRODUCTION}

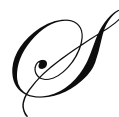

ince its introduction in the late $19^{\text {th }}$ century, business education has grown rapidly and today represents a $\$ 3$ billion a year industry worldwide (Gupta, Gollakota \& Sreekumar, 2005). However the bulk of business education takes place at the undergraduate and graduate level at university while being almost completely ignored as a subject prior to university. Recently, there have been questions about whether business education actually benefits its students, who often pay large sums of money and lose out on potential wages during their study but then end up in the same position as their non-business educated colleagues (Tinker, 2004). This may not be an issue with business education, but rather the current model on how such education is delivered. The answer to this problem may not be to end business education, but rather better incorporate business education into all levels of the educational spectrum.

Kuwait has two public universities, the University of Kuwait and The Public Authority for Applied Education and Training (PAAET). PAAET is further divided into five colleges, which includes the College of Business Studies and the College of Basic Education which trains educators for the Kuwaiti education system. Because teachers often choose specialized disciplines to teach, whether it is a specific subject or grade level, there are fifteen Specialized Departments within the College of Basic Education, as well four Servicing Departments that 
address issues such as curricula development and teaching administration. It is within this structure that the research for this paper is conducted and evaluated.

The focus of this paper is to determine whether introducing business education at the K-12 level is a worthwhile endeavor and whether a Specialized Department within the College of Basic Education at PAAET in order to train educators on how to teach business education to K-12 students based on the perceptions of faculty members from the College of Business Studies and the College of Basic Education at PAAET. Through the use of interviews with faculty members from these two colleges, this paper will examine this proposal and the possible advantages and disadvantages that introducing business education into the general education field may have.

\section{Literature review}

Unfortunately, there is not a lot of available literature in this specific topic, though some of the general literature on business education is helpful for evaluating whether its expansion into the K-12 grade levels would benefit the field in general. Classic texts such as Leverett Samuel Lyon's Education for business (1922) and Herbert Arthur Tonne's Business education: Basic principles and trends (1939) give an overview of what the classic purposes of business education are. Early business education was designed to train stenographers and accountants, but was also designed to help students think strategically about commercial enterprises (Lyon, 1922). As time passed, the goals of business education were also tailored to encourage innovation in creative thinking but also a strategic approach in that thinking. Since these skills were seen as useful to all students, business education was incorporated into the general curriculum of secondary schools in the 1930s and 1940s (Wraga, 1994), but as academia grew as an industry, business and the world of academia were increasingly kept separate with critics claiming that teaching business in secondary school prepared students for a job, but not for further education which should be the purpose of secondary education (Litzinger \& Penley, 1977). As a result, enthusiasm for teaching business education prior to university waned.

Yet more recently groups such as the National Business Education Association in the United States has advocated that these skills - the ability to think strategically and creatively about problem solving - are necessary at all levels of education and are just as applicable to a secondary school student planning on studying philosophy as one who plans to ultimately go into business (Rader \& Kurth, 2003). As corporations become more important in global finance and politics, business knowledge is arguably an important source of knowledge needed to understand the world we live in and not just how to improve profits. It is also an important education to have for handling individual finances and making educated life decisions (Jones, 2009). This perspective on business education is one of the reasons why increasingly educators have looked for ways to incorporate business education into the general education curriculum, a trend that can be seen especially in developed nations such as the United States.

However business education itself has increasingly been questioned, not just for its results but for how it perceives itself. Many researchers have pointed to an increasing gap between the skills needed in the business world and what is actually being taught in business schools (Ehab \& Lashine, 2004), while research by Julia Shaftel and Timothy Shaftel (2007) attempted to use educational assessments commonly applied to K-12 education to business schools to see how business education fares. The application of this assessment to post-secondary business schools found that the focus of business education for students to "choose, create and innovate" left business schools with a great deal of flexibility in producing outcomes (Shaftel \& Shaftel, 2007). Without stronger assessment mechanisms, business education is not required to produce outcomes in the same way that K-12 education is; this conclusion highlights much of what is wrong about post-secondary business education today but also suggests what advantage introducing business education into primary and secondary education can have.

Yet the most common area where the literature discusses the expansion of business education is the need to introduce business skills earlier in the education cycle in order to make it more effective. One situation where this is brought up is in regards to business ethics. Currently, business ethics are taught largely in the business arena and are based on cogitative reasoning. Some researchers have focused on the fact that because this is the current model, it is often easy for people to still justify their unethical actions because they are unaccustomed to using these same skills outside the business school classroom (Park, 1998; Crane \& Matten, 2004). Other research has found that the ethics culture that students learn is often far more influential than what is put in place by the organizations that they later 
work for (Douglas, Davidson \& Schwartz, 2001), and yet ethics education remains weak in most academic settings, leading to bad ethics as an almost inevitable result (Swanson, 2004). This is a conclusion that has been found in relation to business education in several countries, including Kuwait (Al-Kazemi \& Zajac, 1999). As a result, some literature goes a step farther and proposes that business ethics education should be expanded to other educational fields and not limited to post-secondary education (Buff \& Yonkers, 2005). Only by doing so will such lessons actually impact the choices that business students make after they leave school.

Similarly, as the ultimate purpose of business education is to prepare students for the business world, many of the practical skills that business school teaches such as in-depth reading and concise writing skills are also applicable to other areas of study. Thus, intentionally teaching business skills to non-business students and earlier than the university level can help all students be more prepared for the world and for business if they choose to enter it (Stratcher, 2000).

Thus, although the literature is limited, it appears that the bulk of it supports the introduction of a broader business education curriculum, though for varying reasons. But this literature all comes from the view of researchers involved in business education or perhaps the larger business world; none of the authors noted are involved in the general educational field. This is yet another reason why the literature in this area is limited as any evaluation for the expansion or non-expansion of business education must involve the perspectives from both the business world and the field of general education. This is why this paper examines this proposal through the use of interviews with faculty members from the College of Basic Education and College of Business Studies.

\section{Proposed Hypothesis}

The proposed hypothesis of this paper is that by introducing business education earlier in the educational cycle in the K-12 grades, the skills that business school attempts to instill in its students will be more strongly evolved for those who ultimately study business. Furthermore this paper proposes that these skills are also useful to students in other disciplines and the expansion of business education will help broaden their education as well. As a result, the creation of a business studies unit within the College of Basic Education in order to train educators for teaching business in the K-12 education system would be a valuable addition to PAAET.

\section{METHODOLOGY}

Because of the limited literature on the topic, this paper instead relies mainly on semi-structured interviews conducted with six faculty members, three from the College of Basic Education and three from the College of Business Studies. A set list of questions (Appendix 1) was posed to all faculty participants in a telephone interview. The questions addressed the perceived skills learned through business education, the perceived gaps in the current general education model, and their general views on the usefulness of incorporating business education into the K12 education system. This is the basic framework that this study attempts to analyze.

The same questions were posed to both faculty groups for the sake of conformity and in order to better analyze their answers in a uniform matter. The questions were also designed to employ a hermeneutical phenomenology research model where teaching and education are the common experience among all the participants and the narrative study captured their experiences and perspectives (Cresswell, 2007). The analysis of the participants' answers is done in narrative form, instead of trying to quantify their responses. This is done to fully take in the nuances of their responses since this is the beginning stages of research in this area. Further research into this area that builds on this paper could use more quantitative methods in order to further narrow the results.

\section{RESULTS OF THE STUDY}

The following details the responses received during the interviews of faculty members of from the College of Basic Education and the College of Business Studies. The questions posed are divided into four sections: skills sets, perceptions on business education, applying business skills to other populations, and business ethics. 


\section{Skill sets}

The first question posed to faculty members concerned what skills that both faculties would like to see more developed in pre-university education. Despite the differences in the courses taught, the answers given between the two faculties were remarkably similar.

The three faculty members from the College of Basic Education and two of the faculty members from the College of Business Studies expressed that many university students lacked analytical skills and the ability to think independently or creatively when they first arrive at university, however there was differing opinions over whether this was problematic. All three participants from the College of Basic Education expressed to varying degrees that while they would like their students to have more experience in this area prior to arriving at PAAET, they also believed that learning these skills were part of the university experience. Only one of the respondents from the College of Basic Education felt strongly that this was a deficit that pre-university education should correct, with the reason given that without learning these skills earlier in their education, they believed that students too often fell back on bad habits and did not use the analytical skills learned at PAAET with ease.

Among the respondents from the College of Business Studies there was a wider difference in opinion on the analytical skills of incoming students. One of the respondents did not list a lack of analytical skills or the ability to think independently at all, and was consequently the only faculty member from either school to not point to that deficiency. The other two both listed this as a skill set that they wished they would see in their incoming students, but while one believed that this should be corrected through primary and secondary education and represented a serious flaw in the Kuwaiti education system, the other respondent believed that this was to be expected from students of this age and at this level of experience. Both of these respondents did express that they believed a lack of these skills created a stronger "learning curve" that incoming business students had to handle, and was one of the biggest problems that first year business students faced.

Other skills that faculty respondents expressed that they wished their incoming students had included the ability to apply solutions to narrative problems. This was only expressed by the respondents from the College of Business Studies and not by any of the respondents from the College of Basic Education, but was expressed by all three faculty members from the College of Business Studies that were interviewed. The main issue behind this observation appeared to be that while students could look at a mathematical problem and determine what actions were needed to solve it, they lacked the same ability with narrative problems that they were presented, even when the actions needed were quite simple. One of the respondents placed this under the rubric of analytical skills as discussed above, while the other two believed this to be more of a lack of the ability to practically apply common sense. Again, this was named as one of the biggest problems that business students face when first starting their program, and was also listed as one of the chief skills that the College of Business Studies tries to instill in their students through their business education.

\section{Perceptions of Business Education}

The second question asked of the faculty participants concerned their perceptions of business education and the skills that such an education gives to its students. The purpose of this question was to gauge how members of both business and non-business academia view business education in order to better consider their responses to the other questions posed.

Not surprisingly, the faculty members from the College of Business Studies answered closely to what is generally regarded as the mission of business education, mainly that business education allows students to think more innovatively and creatively about how to solve problems in the commercial context. Two of the business faculty respondents also listed the ability to assess and appropriately deal with risk as key skills that business students learn through their business education. All of the respondents stated that these skills are taught to deal with issues that arise in the commercial environment and while these skills could be applied elsewhere, did not necessarily expect them to be. 
The faculty participants from the College of Basic Education all listed risk management and assessment as well, although contrary to the business faculty these responses were applied to both business settings and settings outside the commercial field. In addition to this, the respondents from the College of Basic Education answered with more practical skills, such as how to evaluate markets, turn a profit, start a business, and learn how to market a product as skills that they believed business education taught its students. This was in direct contrast to the very broad answers given by their colleagues at the College of Business Studies.

This contrast was also evident in the case of general perceptions of business education, where respondents from the College of Basic Education viewed business education to be more narrowly defined that their field. Two of the respondents felt that business education in general and the College of Business Studies more closely resembled one of the Specialized Departments within the College of Basic Education rather than the other colleges at PAAET due to its very narrow nature.

Overall, there was more focus on concrete skills and experiences gained through business studies from the College of Basic Education responses than there was from the faculty responses from the College of Business Studies, which focused instead on broader concepts rather than tangible skills.

\section{Applying business skills to other student populations}

Several of the questions posed to faculty participants addressed specifically the concept of expanding business education outside of business school and specifically whether other student populations could benefit from business education. The questions posed were divided into whether the skills listed above could benefit nonbusiness students generally and whether they could benefit student prior to receiving a university level education.

On the first question, respondents from the College of Business Studies strongly felt that the general skills they had attributed to business education could benefit other student populations and could do so through the study of business specifically, without adaptation to other fields of study. One of the respondents stated that the ability to think independently and creatively was a skill that could be learned through the study of other courses, but since it was at the heart of business education, business education had more to offer in this area.

Innovation was listed by two of the respondents as important skills that all students could benefit from, though one of the respondents admitted that some other fields, such as information technology, also taught innovation as a critical skill in their field. Both of these respondents felt that some fields of study, including the arts and humanities, completely lacked the ability to teach or imbue their students with innovative thinking because of the nature of their course subjects. It was these areas where they believed business education could benefit nonbusiness students the most.

The faculty from the College of Basic Education did not feel as strongly as the business colleagues about the transferability of business education to other fields of study. Although they too felt that some aspects of business education, including problem solving, would be useful to other fields, they also felt that in order to be useful they would need to be adapted to that student's field of study; in this situation, it would not be so much the expansion of the study of business so much as the expansion of teaching methods and skill outcomes for other areas of study.

On the second question of whether business education could benefit students prior to receiving a university level education, the responses were actually more strongly in favor of such a proposal than they were for the general question but were not as uniform. From the faculty members of the College of Business Studies, all three respondents felt that business education should be incorporated at some level in the general education that students receiving in grades K-12. Two of the respondents voiced the opinion that doing so would help raise the level of education at PAAET since students would be more prepared for business studies, and presumably other studies done at PAAET, if they had some exposure to these concepts prior to enrollment.

The third respondent from the College of Business Studies did not suggest this, but did note that all Kuwaiti students will ultimately become part of the wider business world, whether they work for a business, organization, or 
the government. While a student may have no plans to "go into" business, it is likely that the concepts and knowledge taught through business education would be useful to them at some point in their careers. Such knowledge would likely help them with promotions at their place of employment and help them understand the problems that their employer faces. He also expressed that since university education places a stronger emphasis on critical thinking than K-12 education, most university graduates would probably be able to do this on their own without specialized business education, but because not all students continue on to university, incorporating business education into the general curriculum prior to university would have a far greater impact than university students from other disciplines studying business as well.

This sentiment was echoed by two of the respondents from the College of Basic Education who pointed out the commercial nature of the Kuwaiti economy and the fact that the practical skills learned through business education were useful for people to understand the world that they live in. In this regard, some aspects of business education could be considered general education as well. Two of the respondents also expressed that business education may provide for a different set of problem solving skills than is currently taught in general K-12 education, and this expansion could benefit students by teaching them to view issues critically instead of accepting the status quo.

However, this last point was disputed by the third respondent from the College of Basic Education who did not believe that critical thinking was a necessary skill for all citizens to have. Although such approaches are taught at university, it is done within the limits of a particular field of study. This participant questioned whether expanding business education for the sake this particular skill was necessary or worthwhile, and believed that there could be hidden dangers in trying to do so. He also questioned whether incorporating business education into general education, particularly the lower grades in the K-12 education system, would ultimately benefit the students or the business community because the knowledge would be too advanced for them to understand.

\section{Ethics}

The final question posed to the six faculty respondents was whether they believed that business ethics specifically should be introduced prior to university for all general education students. Again, the results were mixed but split between the two faculties.

The respondents from the College of Business Studies did not see any real reason why business ethics specifically should be introduced into general education. One of the respondents stated that because the people in charge of making decisions that should be guided by business ethics would likely have already studied business at university, introducing the topic prior to university made little sense while the second respondent believed that the such topics would be too advanced for most students without the proper context, including upper level secondary students. The third respondent from the College of Business Studies was more receptive to the idea than the first two, but felt that the ethics education that is typically taught through other courses was more than sufficient for most general education students and there was no need for any specialized education in business ethics at this level.

In contrast, all three respondents from the College of Basic Education responded well to the idea of introducing business ethics into the general curriculum. Two of the faculty members pointed out that the ethical issues that arise in business transactions often arise in other areas of life, and therefore students could benefit from specialized education that specifically addresses these issues from a business point of view. The other respondent felt that by receiving a specific curriculum module in this area, student could judge reports of scandal and other business news better than if they did not receive the education since they would be more likely to understand the issues involved and have practice, even if only theoretically, in seeing how they would respond to similar situations.

All three respondents from the College of Basic Education expressed the belief that corruption is a major problem in the business world mainly because people do not act ethically in business transactions. One of the faculty participants stated that perhaps if students were taught to think critically about these issues before entering business school, then they would be more likely to act ethically in their business transactions. One of the other participants noted that not all of the people involved in corrupt transactions attend business school, thus introducing business ethics into the general education curriculum might help with corruption problems by exposing these people to the same values education that their business graduate colleagues receive at university. 


\section{DISCUSSION}

Based on the answers received by the interview participants, it is clear that there are some trends in the opinions regarding the proposal to introducing business education into the general $\mathrm{K}-12$ curriculum, however there are also some areas that remain murky. Likewise, while some of the answers received are consistent with the applicable literature reviewed earlier in this paper, some of the answers appear to directly contradict the thinking that has driven previous research in this area. In the end, this study serves as a starting point for further research into the usefulness of establishing a Specialized Department within the College of Basic Education in order to introduce business education to students prior to university.

\section{Analysis of the interview answers}

In addressing whether incoming PAAET students faced a specific skills deficit, the answers generally supported the idea that students typically lacked analytical skills and the ability to think independently, however there was one respondent from the College of Business Studies who did not mention this skill set at all. The fact that the other five faculty participants did mention this skill set suggests that such skills are not taught, or taught effectively, in the general K-12 education system. According to the responses from the College of Business Studies, analytical and independent thinking are core competencies taught in business programs; it is therefore easy to suggest that incorporating business education into K-12 education would increase the abilities of incoming PAAET students in these areas.

However, members from the College of General Education did not express any belief that analytical and independent thinking were part of business education when asked about their perceptions of business as a field of study. Instead, they focused on practical skills such as risk assessment and marketing tools. Therefore, the conclusion that business education helps builds these analytical skills is not an easy conclusion.

Yet knowing which faculty is correct or how to apply these perspectives to the issue at hand provides a separate problem. One possibility is that the business faculty has an unrealistic view of their discipline and the programs outcomes, a view that is supported by some of the literature and statistical data (Shaftel \& Shaftel, 2007). Another possibility is that the fault does not lie with the business faculty, but rather with the members of the College of Basic Education who may not be fully aware of the curriculum offerings and learning methods that business education employs.

This second conclusion is supported by the repeated statement by respondents from the College of Basic Education that business education in general, and the College of Business Studies, was far more narrow than typically found in the colleges at PAAET while members from the College of Business Studies described their field as being far more broad, and at some points, almost abstract in nature. The difference in opinion most likely is the result of unfamiliarity with business studies in general and the exact nature of the curriculum.

Nonetheless, any possibility of creating a Specialized School within the College of Basic Education for the purpose of teaching business education to future K-12 educators would require the desire and approval of faculty members from that college. The resistance of faculty members to the suggestion that business education would be beneficial for these students is therefore problematic to this suggestion. It is possible that with further sensitization of the College of Basic Education faculty that their opinions would change, but this is by no means certain. Thus, this is the first issue raised by this research again establishing such a school.

The second issue raised is related to this as well: the usefulness of business skills for other student populations. Again, the faculty members from the College of Business Studies generally believed that business skills would aid other student populations in their own studies while members of the College of Basic Education questioned that assumption.

In this case, it was not as much of an outright contradiction as was the case with faculty perceptions of business studies, but rather a more measured response to the question at hand. The responses from all three participants was that such training may be useful, but would need to be adapted to the student's specific field of 
study in order to be of the biggest benefit to them. This could be because the student populations considered here were other university students who throughout the interviews were differentiated from K-12 students in terms of their reasoning skills at the end of their academic careers. Because all of the participants from both the College of Basic Education and the College of Business Studies appeared to believe that university graduates would gain the same analytical skills offered by business studies regardless of their course of study, this measured answer may be in response to these faculty members expectations of the skills that other student populations would leave PAAET with and what they would be expected to do following university.

This conclusion is supported by the much stronger belief by both faculties that business education could be beneficial if incorporated into some level of the general K-12 education scheme. Though the reasoning behind this assertion varied by faculty and by individual respondents, the general sentiment was that students who do not continue onto university education would benefit more than university graduates in receiving some form of business education. On the part of the respondents from the College of Basic Education, this was mainly to prepare these students for what tasks might be demanded of them later in their careers, while the respondents from the College of Business Studies were more concerned with improving the quality of students that entered PAAET. Nonetheless, it is important to note that despite varying opinions expressed earlier about the usefulness of business education in general, participants from both faculties largely supported the concept of some form of business education entering the K-12 curriculum.

The only respondent to disagree with this assertion represented a more conservative view that was perhaps motivated by fears of what unchecked thinking would mean for Kuwaiti society as a whole. This does not mean that their opinion is not valid, and in fact probably represents a view that others would have if business education was introduced into the K-12 curriculum and was presented as a method of allowing more critical and independent thinking on the part of students. Thus, in order for any venture of this type to be successful, administrators would need to think about exactly what types of skills they are trying to impart through business education and make sure that it met the expectations of society as a whole. This is especially true given PAAET's status as a government institution that is funded by the state.

The last question posed to the participants concerned the specific topic of business ethics. This question was included in the list because of the emphasis in the literature in the importance of teaching business ethics young and because of the high profile manner of scandals and corruption cases. It is a reality that most of the time the general public hears about or pays attention to news of the business world it is because of a scandal. The purpose of business ethics is to prevent such things from happening. As a result of the many recent international business ethics scandals, including but not limited to Enron, WorldCom, and Iraq's Oil for Food Program among others, business schools are reconsidering their approach to ethics in order to adapt to the apparent ease of corruption in the corporate environment (Sims \& Felton, Jr., 2006). One such approach advanced in the United States includes introducing the topic to student through general education prior to business school (Niederjohn, Nygard \& Wood, 2009).

Therefore it is interesting that in this context it was the faculty members from the College of Basic Education who most strongly supported the idea, while the respondents from the College of Business Studies were mostly indifferent to the proposal. However in this context it was also not surprising that all three respondents from the College of Basic Education named concerns about corruption as a motivating factor in their opinion. As people outside of the corporate world, perhaps this is to be expected. But without the support of people from the corporate world, here represented by the College of Business Studies faculty, it remains unclear how viable the project would be.

The reasons given by the respondents from the College of Business Studies are understandable, namely concerns about whether such limited education would be effective for students later in their careers because of the complexity of the topic or the context in which it was believed it will be taught in a general education curriculum. However, given the strong responses earlier in the study by these same respondents in favor of improving the quality of students admitted to PAAET and honing independent think skills, this display of apathy seems contradictory. 
It is possible that respondents felt that encouraging the teaching of business ethics on a general education level would increase the amount of attention being given to corporate scandals and perhaps reflect badly on the business world. Yet it is impossible to tell whether the reasoning behind these opinions in sincere or not, or whether such opinions are broadly supported in the Business Studies faculty given the small sample size and limited follow up done for the purposes of this paper. Thus, while the concept of introducing business ethics to the K-12 curriculum appeared to garner the most support from the College of Basic Education and could be a good starting point from which to introduce business education to the pre-university system, it also appears based on the attitudes of the College of Business Studies faculty that there are major obstacles that would have to be overcome for it to actual happen.

\section{Results compared to previous research}

It is difficult to assess the quality or reliability of this study compared to previous research because there is so little research that has been completed addressing this question, and none of the research studied for this paper addressed Kuwait specifically. There are serious questions regarding how business schools perceive themselves and the actual gain given to student who attend these programs (Shaftel \& Shaftel, 2007). It would appear based on the interviews with the faculty members from the College of Business Studies that this may also be an issue at PAAET in light of their responses which seemed to possibly overstate the importance and value of business education compared to their colleagues at the College of Basic Education. However, as mentioned previously this could also be due to a misunderstanding or false understanding on the part of the College of Basic Education into what business education entails. It is however interesting that the answers given on the strengths of business education by respondents from the College of Business Studies closely mirrored the classic view of business education espoused by academics early in the $20^{\text {th }}$ century (Lyons, 1922). This lack of change despite overwhelming change that the business world and business education has gone through in the decades since these classic texts may suggest that Shaftel and Shaftel (2007) were correct in their assessment that business schools and their faculties are often guided more by an ideal vision of themselves than what is the reality.

Another area where the literature proposes the expansion of business education into the K-12 education system is with business ethics. Most literature reviewed for this paper encouraged this expansion as a way to better instill business ethics into future business students (Crane \& Matten, 2004). Buff and Yonkers (2005) even encouraged the strategic use of student codes of ethics as a method of teaching business ethics, both at the secondary school level and university. It is therefore surprising that little support came from the College of Business Studies faculty. Yet, the research reviewed here was completed in other countries where the social and cultural systems differ from Kuwait. While this is one possible explanation, the answers received here clearly contradict the current literature available on the topic.

However the answers from the participants here do appear to support the literature in contemplating whether business skills are transferable to other disciplines and constitute a useful skill for general students. This is the case insofar as there is no clear answer in the literature and no clear answer was given through the interviews conducted for this paper. While some researchers advocate that the skills learned in business school are skills that are applicable to all fields of study (Stratcher, 2000), others question not only the applicability of the skills but the future of business education in general (Tinker, 2004). Likewise, on the whole there did not appear to be any clear answer given from the respondents whether they belonged to the College of Basic Education or the College of Business Studies. Thus this remains a murky area in terms of any proposal to establish a Specialized Department within the College of Basic Education for the teaching of business studies to students enrolled in K-12.

\section{Limitations and areas of further research}

Although this study attempted to examine the need and viability of creating a Specialized Department within the College of Basic Education for the purpose of expanding business education to the K-12 education system, there is no final answer for that question available here. This is because the interviews completed only represent a small portion of the faculty community of both the College of Business Studies and the College of Basic Education who would have to work together to develop and implement such a proposal. 
In this regard, these interviews are more akin to a sampling rather than a complete study; further and more extensive research would need to be done in order to determine whether such a Specialized Department would benefit K-12 students and their general education. Areas where this research is needed include a review of the standard curriculum for business education, the perspectives of practices K-12 teachers, the modern purpose of business education, and the opinions of society at large for the modification of the general education system in this manner. Because the expansion of business education into the K-12 curriculum would affect the entire Kuwaiti educational system, the opinions and perspectives of the relative faculty members from the University of Kuwait would also be worth researching. While some possible issues are brought up here, including differing opinions on the purpose and outcome of business education, this only serves as a starting point, not the final answer.

\section{CONCLUSION}

This paper attempted to assess the usefulness and viability of expanding business education to the K-12 general education and establishing a Specialized Department within the College of Basic Education at PAAET. The proposed hypothesis was that doing so would ensure stronger business skills among students who study at the College of Business Studies and could also benefit students who study non-business disciplines. Through interviews conducted with faculty members from the College of Basic Education and the college of Business Studies, this hypothesis was evaluated using the perspective and opinions of these decision makers at PAAET.

In the end, while there is some support for this hypothesis more research is needed in order to prove or disprove the hypothesis. There is some belief among these faculty members that expanding business education to general education prior to university can improve the quality of students admitted to PAAET, improve critical thinking skills, and may help curb corruption in business but the opinions expressed are too broad and diverse to definitively state a conclusion. The fact that some of the perspectives expressed contradict current research and academic thinking on these issues also leads to the conclusion that further research is needed.

However, even if the proposed hypothesis could not be proven with this study, this does serve as a good starting point for further research. More specific research into perspectives and opinions in Kuwait on the importance and usefulness of business education will enable future researchers to determine whether it is in the best interest of Kuwaiti K-12 students to expand business education and establish a Specialized Department within the College of Basic Education in order to do so.

\section{AUTHOR INFORMATION}

Dr. Abdullah AlSagheer, has $\mathrm{PhD}$ in Education and Human Resource Studies specialized in Interdisciplinary Studies (Ergonomics and Strategic Management) and Master in Human Resource Studies. He received Bachelor of Science in Computer Engineering, a double major in Bachelor of Science in Electrical Engineering and Master of Science in Electrical Engineering from California State University Long Beach. He worked at Elite International Company. He has taught at CSULB and CSU. His research focuses in Strategic Management, Capstone Courses, Entrepreneurship and Leadership for Engineer, Curriculum Development for Engineering and Science Education, Human Resource studies for Engineering Field, Management Training and Education.

Areej Al-Sagheer, worked as Senior Accountant in Kuwait Petroleum International Limited (KPI-Q8). Al-Sagheer received her Bachelor of Science in Accounting \& Auditing from Kuwait University. Al-Sagheer is currently doing her MBA at Colorado State University. She has experience in the industrial field as Assistant Accountant Treasurers in the Kuwait Oil Tankers Company (KOTC) and Financial Assistant / General Accountant and then Senior Accountant in the Kuwait Petroleum International Limited (KPI-Q8) from January, 1997 till today. Her research focuses Audit Accountancy, Business Leadership, Business Education, Corporate Finance, Risk Management and Human Resource Studies. 


\section{REFERENCES}

1. Al-Kazemi, A.A. \& Zajac, G. (1999). Ethics sensitivity and awareness within organizations in Kuwait: An empirical exploration of espoused theory and theory-in-use. Journal of Business Ethics, 20, 353-362.

2. Buff, C.L. \& Yonkers, V. (2005). Using student generated codes of conduct in the classroom to reinforce business ethics education. Journal of Business Ethics, 61, 101-110.

3. Crane, A. \& Matten, D. (2004). Questioning the domain of the business ethics curriculum. Journal of Business Ethics, 54, 357-369.

4. Cresswell, J.W. (2007). Qualitative inquiry and research design: Choosing among five approaches (2nd ed.). Thousand Oaks, CA: Sage Publications.

5. Douglas, P.C., Davidson, R.A. \& Schwartz, B.N. (2001). The effect of organizational culture and ethical orientation on accountants' ethical judgments. Journal of Business Ethics, 34, 101-121.

6. Gupta, V., Gollakota, K. \& Sreekumar, A. (2005). Quality in business education: A study of the Indian context. In J.R. McIntyre \& I. Alon (Ed.), Business and management education in transitioning and developing countries (pp. 3-21). New York: M.E. Sharpe Inc.

7. Jones, B. (2009, May 12). ACC business day gives students a chance to hone business skills. McClatchyTribune Business News [online]. Retrieved October 10, 2009 from ProQuest Newspapers database.

8. Litzinger, W.D. \& Penley, L. (1977). High School Business Education Vis-A-Vis Collegiate Education for Business. Balance Sheet, 59, 104-141.

9. $\quad$ Lyon, L.S. (1922). Education for business. Chicago: University of Chicago Press.

10. Mohamed, E.K.A. \& Lashine, S.H. (2004). Accounting knowledge and skills and the challenges of a global business environment. Managerial Finance, 30, 73.

11. Niederjohn, M.S., Nygard, K. \& Wood, W.C. (2009). Teaching ethics to high school students: Virtue meets Economics. Social Education, 73(2), 76.

12. Park, H.J. (1998). Can business ethics be taught? A new model for business ethics education. Journal of Business Ethics, 17, 965-977.

13. Rader, M.H. \& Kurth, L.A. (2003). Effective methods of teaching business education in the 21st century. Washington, DC: National Business Education Association.

14. Shaftel, J. \& Shaftel, T.L. (2007). Educational assessment and the AACSB. Issues in Accounting Education, 22, 215-232.

15. Sims, R.R. \& Felton, Jr., E.L. (2006). Designing and delivering business ethics teaching and learning. Journal of Business Ethics, 63, 297-312.

16. Stratcher, D.A. (2000). How right do you write? The marriage of business and education. In S.M. Natale (Ed.), Business education and training: A value laden process (pp. 135-147). Lanham, MD: university of America Press.

17. Swanson, D.L. (2004). The buck stops here: Why universities must reclaim business ethics education. Journal of Academic Ethics, 2, 43-61.

18. Tinker, T. (2004). The end of business schools? More than meets the eye. Social Text, 22, 67-80.

19. Tonne, H.A. (1939). Business education: Basic principles and trends. Ann Arbor, MI: University of Michigan.

20. Wraga, W.G. (1994). Democracy's high school: The comprehensive high school and educational reform in the United States. Lanham, MD: University Press of America. 


\section{APPENDIX 1}

\section{A semi-structured Interview questions regarding teaching business in K-12 education:}

1. What skills do you think your students sometimes lack that you think should be a bigger part of preuniversity education?

2. How do you view business education today? What skills do you think it imparts to students who study business?

3. Would these skills benefit other students who are not planning on going into business?

4. Do you think there are any benefits of teaching business skills in general education before university?

5. Do you think that general educators would benefit from business education?

6. If business ethics were taught earlier in the education cycle, do you think ethical standards would be better than they are today? 